\title{
INCREDIBLE CAPPARIS DECIDUA (FORSK.) EDGEW: AN INCLUSIVE EVALUATION OF PHYTOCHEMISTRY, PHARMACOLOGY AND NUTRAPHARMACEUTICAL POTENTIALITY
}

\author{
Bina Rani ${ }^{1}$, Suman Panwar ${ }^{2}$, Upma Singh ${ }^{3}$, MM Abid Ali Khan ${ }^{4}$ and Raaz K. Maheshwari ${ }^{* 4}$ \\ ${ }^{1}$ Department of Applied Science \& Humanities, IIMT College of Engineering, Greater Noida (U.P.) \\ ${ }^{2}$ Department of Geography, Jai NarainVyas University, Jodhpur (Rajasthan) \\ ${ }^{3}$ Department of Applied Chemistry, School of Vocational Studies \& Applied Science, \\ Gautam Buddha University, Gautam Buddha Nagar (U.P.) \\ ${ }^{4}$ Department of Botany Shia PG College, Lucknow (U.P.) \\ ${ }^{5}$ Department of Chemistry, SBRM Govt PG College, Nagaur, Rajasthan
}

\section{Review Paper}

\begin{abstract}
Capparis decidua (Forsk.) is a densely branching shrub or small tree found growing naturally in arid and semiarid areas of India. In Rajasthan, it occurs both on sandy and gravelly soils covered with sand dunes. C. decidua, climbing up to 5-6 meters in height, is widely used in traditional medicinal system of India. Medicinally, it is used to treat in cardiac and gastric troubles. It consists of alkaloids, phenols, sterols and glycosides. Aqueous extract of the plant exhibits anthelmintic activity; seeds contain antibacterial principles-glucocapparin; isothiocyanateaglycone of glucocapparin. The fruit has been shown to possess anti-atherosclerotic, antidiabetic, anti-hypertensive, and anti-hyperlipidemic properties. The cardiovascular activity of capparidisine, a spermidine alkaloid from Capparis decidua, has been reported. Besides many socioeconomic and ecological benefits, all parts of this plant provides varied nutritional folk medicinal uses of $C$. deciduas are well known, so it is essential to summarize a comprehensive review on related aspects of $C$. decidua plant. Therefore, the present review manuscript focuses on the detailed profile of valuable nutrients and biochemical compounds as well as medicinal wellness of Capparis decidua.
\end{abstract}

Keywords: Analgesic, Diaphoretic, Alexeteric, Laxative, Anthelmintic, Rheumatism, Amino acids, Tocopherols, Phytochemicals.

\section{INTRODUCTION}

Capparis decidua (Forsk.) Edgew. commonly known as Kair, is an important indigenous shrub found growing along farm boundaries, orans, gochars (local grasslands) and wastelands, widely distributed in arid and semi-arid tracts of India. It is a densely branched shrub, reaching a height of $4-5 \mathrm{~m}$, with a clear bole of $2.5 \mathrm{~m}$.

Its branches are tender and waxy with rough, corky, gray bark. Kair has the ability to survive in various habitats and can grow unattended and unprotected on barren lands1,2. It has good soil binding capacity, a fair tolerance to salinity and alkalinity, and can help to improve the fertility of sand dunes and reduce alkalinity.

Its xerophytic qualities, including a deep taproot system, scanty foliage, mucilaginous sap and tough conical spines make this shrub suitable for cultivation on a large scale, especially to combat soil and wind erosion on sandy wastelands. Significantly, the plant's unique capacity to tolerate drought and heat make it a good weather forecasting species, and it has played an important role in

*Corresponding author: rkmgreenchem.jaipur@gmail.com 
the rural economy of western Rajasthan and Gujarat. It provides people with food (pickle and vegetable), medicine, fodder, wood for carving, and fuel3.

The plant's mature fruits serve as valuable and integral source of nutrition for villagers of arid and semiarid regions, and the immature fruits are collected from natural stands and serve an additional source of income and nutrition for the rural poor.
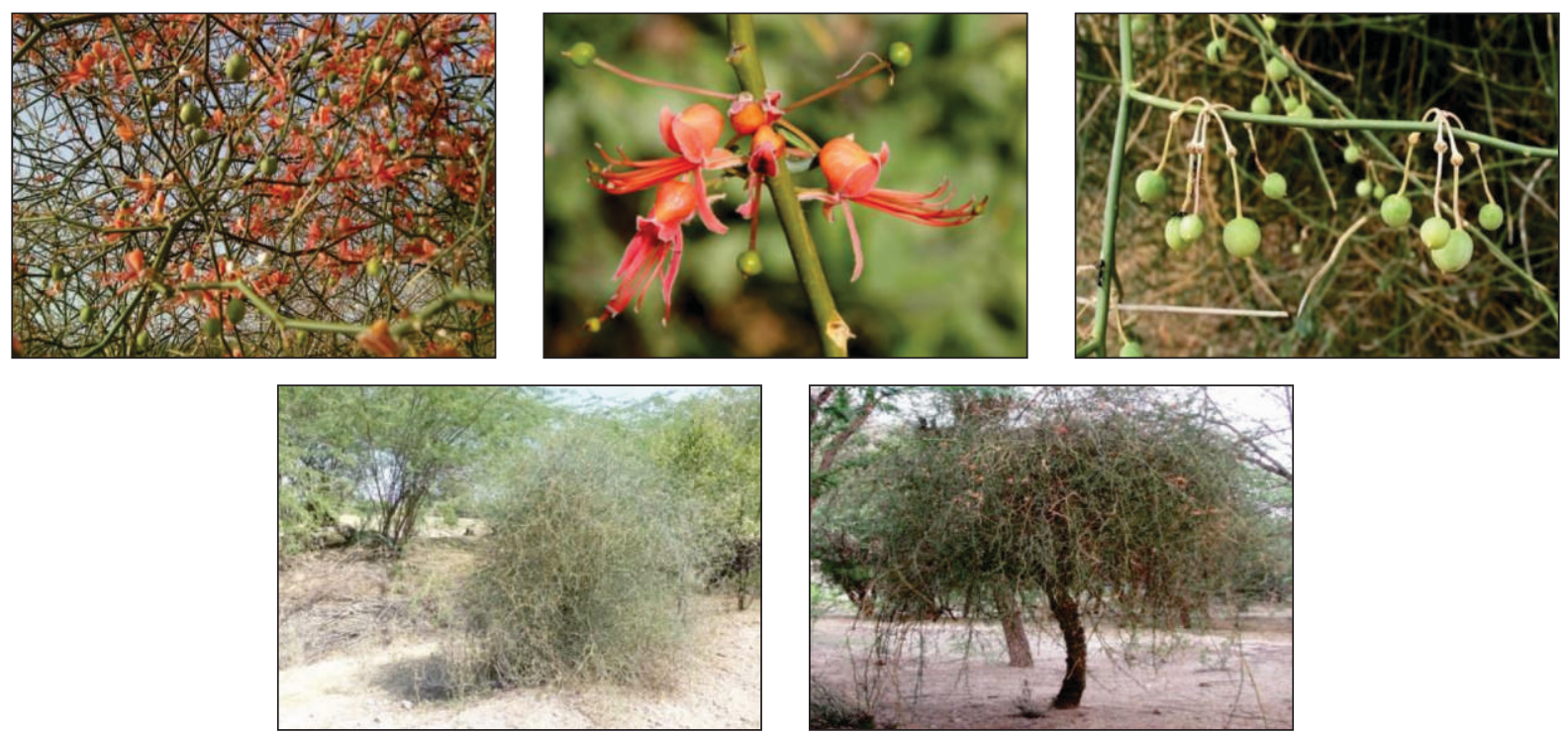

Ethanomedicinal value Traditional Uses of $C$. decidua

Medicinally, it is used to treat in cardiac and gastric troubles4. It is also commonly used as a biofence and its termite-resistant wood is used by rural people for making handles, cartwheels, and other items. In accordance with the texts mentioned in Ayurveda manuscripts, the bark has an acrid, sharp, hot taste; analgesic, diaphoretic, alexeteric, laxative, in dropsy ground, anthelmintic; good in asthma, ulcers and boils, vomiting, piles and all inflammations.

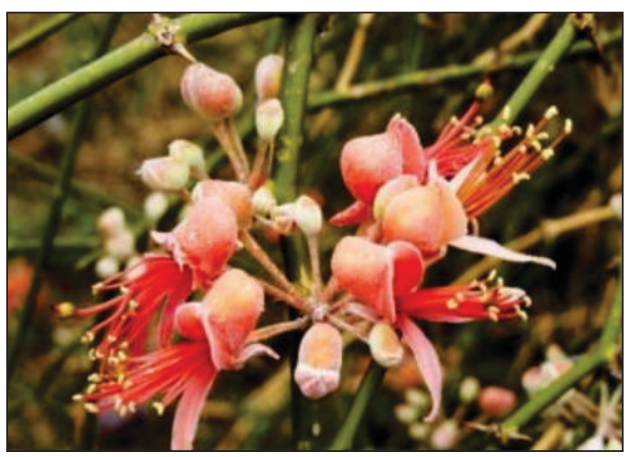

Anti-inflammatory, anti-asthmatic, anthelmintic, purgative, hepatoprotective, antidiabetic, hypolipidaemic, anti-atherosclerotic and antimicrobial activities are the pharmacological activities reported for the plant5-8. The root bark is pungent and is given in cases of intermittent fevers, asthma, inflammations and rheumatism. It is applied externally to ribs in case of pleurisy.

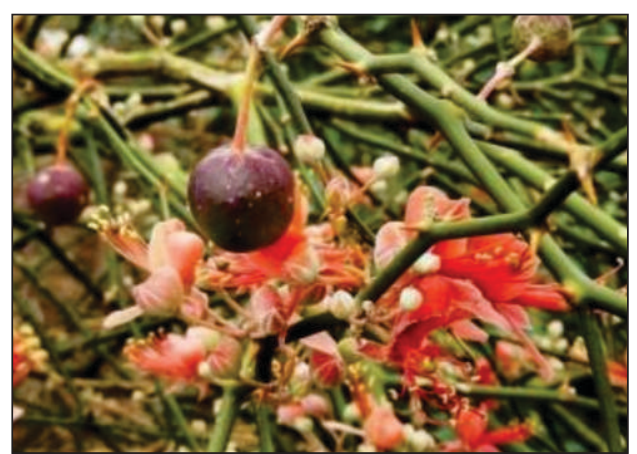


The green immature fruits are considered antihelminthic and laxative and are employed in the treatment of asthma, constipation, coughs, hysteria and other psychological problems. Different extracts of the plant possess pharmacological properties10-14. The plant has been reported for its CNS sedative and depressant, and antimicrobial properties, Methanol and water extracts of $C$. decidua possessed hepatoprotective activity. The effects of extracts of the plant on human plasma triglycerides, total lipids and phospholipids have been reported The fruit has a sharp hot astringent to the bowels; destroys foul breath, biliousness, and urinary purulent discharges; good in cardiac troubles.15-17. The fruit has been shown to possess anti-atherosclerotic, antidiabetic, anti-hypertensive, and antihyperlipidemic properties. The cardiovascular activity of capparidisine, a spermidine alkaloid from Capparis decidua, has been reported. .The fruit has been shown to possess anti-atherosclerotic, antidiabetic, antihypertensive, and anti-hyperlipidemic properties. The cardiovascular activity of capparidisine, a spermidine alkaloid from Capparis decidua, has been reported. It is quite obvious that Capparis decidua is known to possess antidiabetic, sedative, anticonvulsant, hypolipidemic, hypocholesterlemic, hepatoprotective and anthelmintic activities18-20. According to the well known versatile medicinal properties and pharmacological actions of Capparis decidua, the present article provides an updated account of different aspects of the phytochemical and pharmacological properties.

C. decidua has been recognized by traditional healers and tribal since long time. They are using different parts of the plant for treating various ailments. The root is used as antibacterial, expectorant, stimulant, thermogenic, sudorific, carminative, aphrodisiac, anodyne, anthelmintic, and anti-arthritis. It is also used in the treatment of dyspepsia, constipation, lumbago, odontalgia, amenorrhoea, scorpion string and dysmenorrhoea. It is taken in different form as decoction of root is used in fever and jaundice treatment, powder is taken with water in liver problems [8, 10]. Root bark is used as alterative, acrid, astringent, alexeteric and diaphoretic. Its extract is used to treat haemorrhoids.21-25 In the case of pleurisy, its powder is applied on ribs externally. Its powder or infusion is used in treatment of joint pains, gout, intestinal worms, as antidote in poisoning, cough, dropsy, palsy, asthma, for intermittent fever, malignant ulcer and boils etc. Decoction of stem and leaves are used to treat pyorrhoea. Fresh twig decoction and aqueous extract of stem are used to cure jaundice. Similarly stem bark is also used in different way for treatments. Decoction of stem bark used to treat asthma and other respiratory disorders. Whereas Crushed bark of the plant is used for treatment of wounds. Tender shoot and fresh leaves are used in toothache, blister and swelling. Flower buds are eaten raw to treat stomached whereas flowers are used to sooth pain and increase erection. Fruits are considered to cure diabetes, convulsions, constipation, cardiac problem, biliousness, halitosis etc. Mixture of fruit powder and sugar in equal quantity is used to cure rheumatism.. It is also useful in enlarged spleen and facial paralysis26-30.

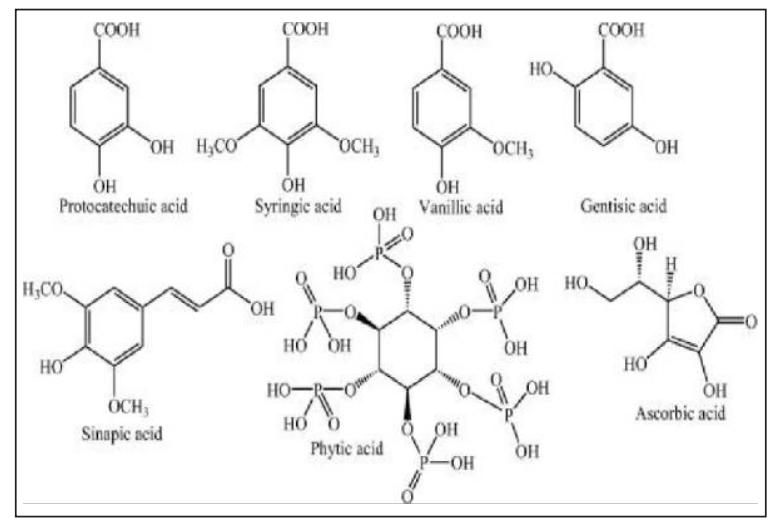

\section{Phytoconstituents of $\boldsymbol{C}$. deciduas}

Capparis decidua seeds are rich sources of all three major food components, i.e. carbohydrates, lipids and proteins9. C. decidua possess alkaloids, glycosides, terpenoids, sterols, flavanoids, phenols and fatty acids having high contents of isothiocyanateglucoside, glucocapparin, stachydrine, ntriacontane, $\beta$-carotene, $\beta$-sitosterol, n-triacontanol, n-pentacosane and phthalic acid. It possesses sufficient amounts of both essential and non-essential amino acids. Unsaturated fatty acids are present in abundance, while all major tocopherols are present in significant amounts. It is known as a rich source of alkaloids, phenols, sterols or glycosides which might be medicinally important and/or nutritionally valuable. It contains npentacosane, n-triacontane, n-triacontanol, 2-carboxy1 1-dimethylpyrrolodine, 6-(1-hydroxy-non-3-enyl) tetrahydropyran-2-one, ß-sitosterol, ß-carotene, ascorbic acid, proteins, total carbohydrates, minerals viz. Ca, K, P, Zn, Fe, Mn. 


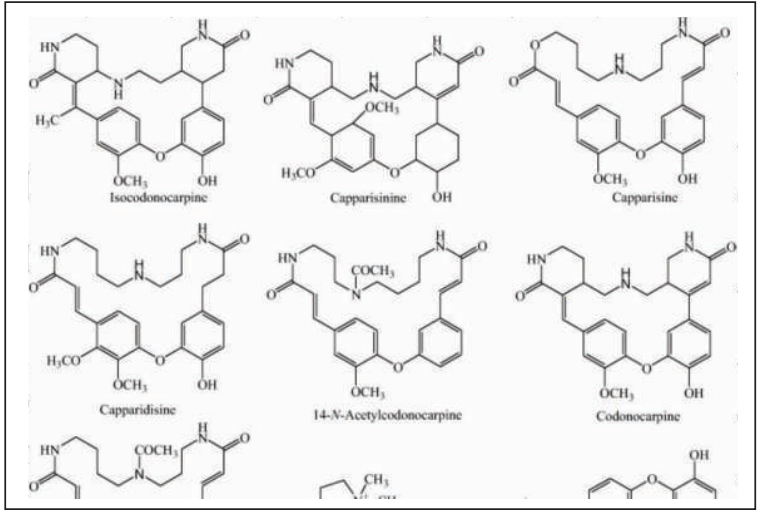

The roots contain the indole bases capparin, capparilin and capparinin. It is quite obvious that Capparis decidua is known to possess antidiabetic, sedative, anticonvulsant, hypolipidemic, hypocholesterlemic, hepatoprotective and anthelmintic activities 23.
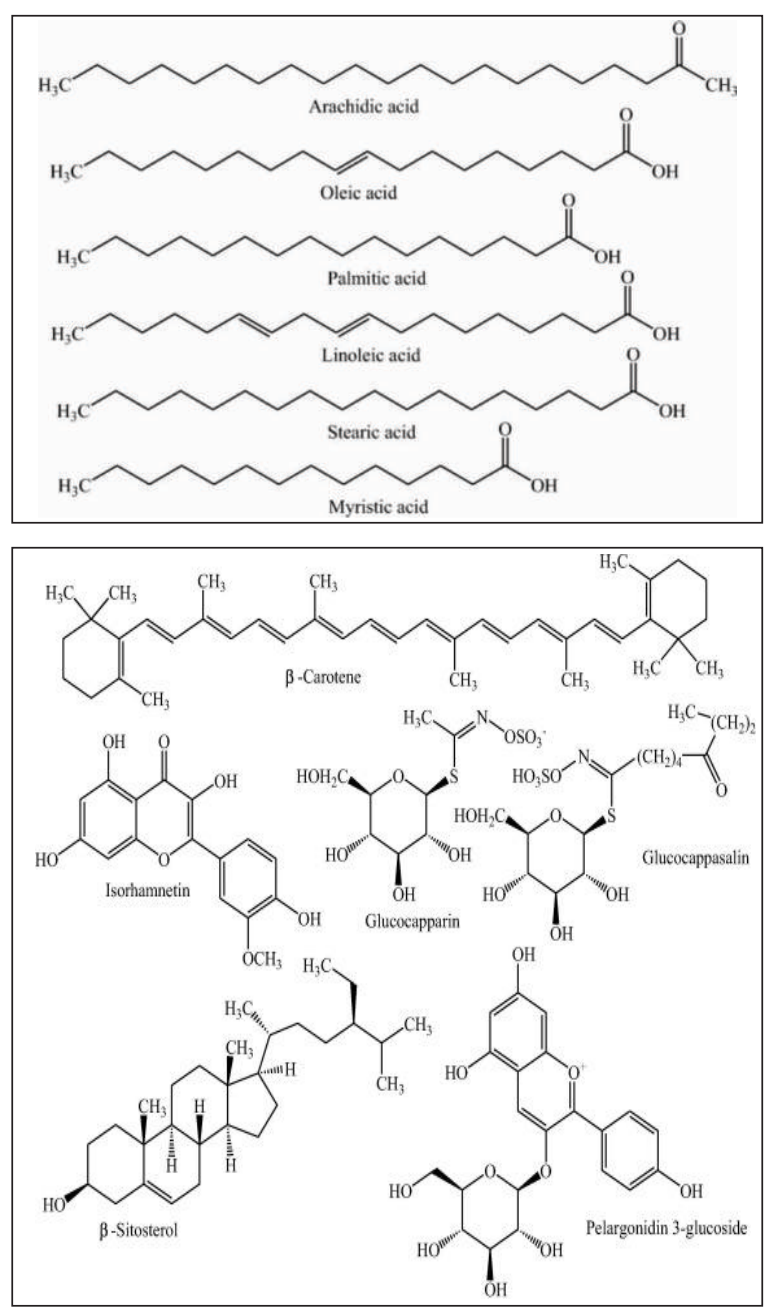

Various phytoconstituents have been isolated from C. decidua -sistosterol, spermidine alkaloid, isocodonocarpine, as Capparine, Cappariline, Capparinine from root; spermidine alkaloids, Isocodonocarpine, Capparidisine and Capparisinine, $\mathrm{N}$-acetylated spermidine alkaloids, Capparisine, Codonocarpine, Cadabacine, Rutinl Stachydrine, $\beta$ sitosterol, 6-oxygenated heterocyclic constituents, like Capparisesterpenolide, Cadabicine, Stachydrine, Rutin, codonocarpine and Deciduaterpenolides A, B, C, D and E from root bark. Plant stem contains two alkaloids n-triacontanol, 2-carboxy-1, 1-dimethylpyrrolodine (stachydrine) [5]. Capric acid and a glucoside isolated from flower buds when boiled with sulphuric acid yield isodulcite and quercetin like compound respectively. Nonacosane, npentacosane, n-triacontane, triacontanol and $\beta$-sitosterol isolated from flower25. Different Glucosides as (6S) -ionlglucosidescorchoionoside C (6S, 9S)-hydroxyl3-oxo- roseside) prenylglucoside, cappariloside A and B, 1H-indole3 acetonitrile glycosides; Biflavonoids, Isoginkgetin, Ginkgetin, Sakuranetin, P- hydroxyl benzoic acid, 5- (Hydroxymethyl) furfural, Bis (5formyl furfuryl) ether; -D fructofuranosides methyl, Uracil,Sterols Daucosterol, stachydrine, cadabicine P-hydrobenzoic acid etc. were isolated from fruit. Mature fruit contain more or less similar compounds as immature fruit except methylstachydrine, hydrocinnamic acids, phthalic acid, cappariside, 4hydroxy-5 methylfuran 3-carboxylic acid, isocodonocarpine etc. Isothiocyanateglucoside named Glucocapparin, Methyl isothiocyanate, npentacosane, n-triacontanol and $\beta$-sitosterol are identified in seed, flowers and fruit husk. Fruit husk also contain ascorbic acid \&phthalic acid.36-44

\section{Pharmacological Findings}

Several chemical and pharmacological researches have been carried out on C. decidua Sterols [45], fatty acids [46], flavones [47], oxygenated heterocyclic constituents [48], alkaloids [49-54], and an isothiocyanate glucoside [55] have been reported in different parts of this plant. The nutritional value of flowers and fruits of $C$. decidua was also evaluated [56,57]. Different extracts of the plant have been demonstrated to possess pharmacological properties. The plant has been reported for its Central Nervous System sedative and depressant [58,59], and antimicrobial properties, $\{60,61]$. Methanol and water extracts of $C$. decidua possessed hepatoprotective 


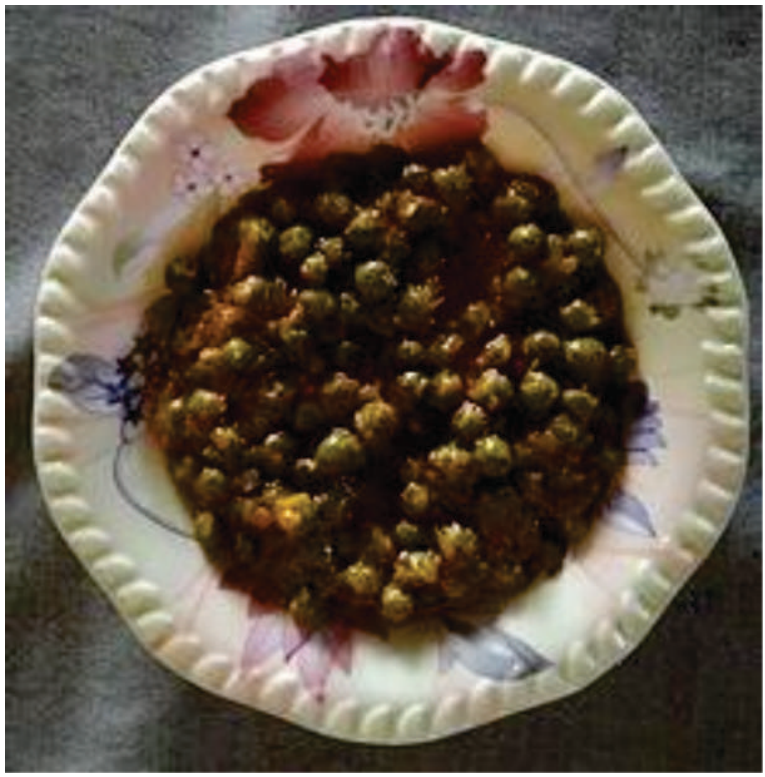

activity [62]. The effects of extracts of the plant on human plasma triglycerides, total lipids and phospholipids have been reported [63]. The fruit has been shown to possess anti-atherosclerotic [64], antidiabetic [65,66], anti-hypertensive [67], and antihyperlipidemic $[68,69]$ properties. The cardiovascular activity of capparidisine, a spermidine alkaloid from Capparis decidua, has been reported $[9,70]$.

\section{Culinary Uses}

Besides their medicinal utility these plants are playing important roles in life of common people. They are using the berries of $C$. decidua and the pods of P. cineraria for culinary purpose. Green berries are used in in the preparations of pickles. The spicy taste fruits serve as an astringent for bowels, a remedy for bad breath and is claimed to cure cardiac troubles. The blanched fruit is used as a vegetable. Seeds oil is edible when processed and also used to cure skin diseases. Vegetable prepared from fruits in ghee is considered good for eyes12-14.

\section{CONCLUSION}

The innumerable medicinal properties and therapeutic uses of Capparis decidua as well as its phytochemical investigations prove its importance as a valuable medicinal plant. The plant is used for its medicinal value in diabetes, rheumatism, hypertension and various stomach problems. The top shoots and young leaves are made into a powder and used as a blister; they are also used in boils, eruptions and swellings and as an antidote to poison. They are very efficacious in relieving toothache when chewed, a decoction of ground stems and leaves is used for pyorrhoea. The fruits are astringent, are useful in cardiac troubles. The young flower bud and fruits are pickled. Fruits are eaten either green or ripe. Useful in facial paralysis and solves problems of enlarged spleen, kills intestinal worms. It is given in phthisis, heart diseases and scurvy. Juice of fresh plant is dropped into the ear to kill worms. Root powder is taken with water in liver problems. Wood being very strong and durable is used to make the foundations around the wells and as fire wood. Flower buds are eaten to relieve stomach ache; root paste is applied on scorpion bite; powdered coal from stem is taken during fractured bone. The bark pout has anthelmintic, constipative and purgative. According to the well known versatile medicinal properties and pharmacological actions of Capparis decidua, the present article provides an updated account of different aspects of the phytochemical and pharmacological properties. C. decidua (Kair) has proven to be an economically important plant in Rajasthan and elsewhere.

\section{ACKNOWLEDGEMENT}

Dr. Suman Panwar is pursuing her Post Doctoral Fellowship project funded by ICSSR, New Delhi under supervision of Prof. Jai Singh, Department of Geography, Jai Narain Vyas University, Jodhpur, Rajasthan.

\section{REFERENCES}

1. Mohammed MS, Khalid HS, Osman WJ, Muddathir AK. A Review on Phytochemical Profile and Biological Activites of Three AntiInflammatory Plants used in Sudanese Folkloric Medicine. American Journal of Pharm Tech Research. 2014; 4(4):1-4.

2. Upadhyay RK. Kareel plant: A natural source of medicines and nutrients. International Journal of Green Pharmacy (IJGP).2011; 5(4).

3. Singh D, Singh RK. Kair (Capparis decidua): A potential ethnobotanical weather predictor and livelihood security shrub of the arid zone of Rajasthan and Gujarat. Indian Journal of Traditional Knowledge. 2011; 10(1):146-155.

4. Sharma P and Sharma DK. (2018). Medicinal value of three common plants of Rajasthan, India: Review Journal of Medicinal Plants Studies 6(1): 96-101. 
5. ChishtyS and Bissu M. (2016) Medicinal and Nutritional Importance of C. decidua (Forssk.) Edgew. (Capparaceae): A Review, International Journal of Science and Research 5(2) :141-147.

6. Singh D and Singh RK. (2010). Kair (capparis decidua): A potential ethnobotanical weather predictor and livelihood security shrub of the arid zone of Rajasthan and Gujarat. Indian journal of traditional knowledge 10(1):146-155.

7. Haq MZU, Ćavar S, Qayum M, Imran I. and de Feo V., (2011). Compositional Studies: Antioxidant and Antidiabetic Activities of Capparis decidua (Forsk.) Edgew. Int J Mol Sci. 2011 ; 12 (12): 8846-8861. do i : 10.3390/ijms 12128846

8. Mahla H.R., Mertia R.S., Sinha N.K. Morphological characterization of in-situ variability in kair (Capparis decidua) and its management for biodiversity conservation in Thar desert. Open Access J. Med. Aromat. Plants. 2010;1:45-46.

9. Joseph B., Jini D. A medicinal potency of Capparis decidua-A harsh terrain plant. Res. J. Phytochem. 2011;5:1-13.

10. Singh P., Mishra G., Sangeet S., Srivastava K.K., Jha K., Khosa R.L. Traditional uses, phytochemistry and pharmacological properties of Capparis decidua: An overview. Der Pharm. Lett. 2011;3:71-82.

11. Singh D., Singh R.K. Kair (Capparis decidua): A potential ethnobotanical weather predictor and livelihood security shrub of the arid zone of Rajasthan and Gujrat. Indian J. Tradit. Knowl. 2011;10:146-155.

12. Agarwal V., Chavan B.M. A study on composition of hypolipidemic effect of dietary fiber from some plant foods. Plant Foods Hum. Nutr. 1988;38:189-197. ].

13. Sharma B., Kumar P., Joshi S.C. Topical treatment of dermatophytic lesion on mice (Musmusculus) model. Indian J. Microbiol. 2011;51:217-222.

14. Rathee S., Mogla O.P., Rathee P., Rathee D. Quantification of $\beta$-sitosterol using HPTLC from Capparis decidua (Forsk.) Edgew. Pharma Chem. 2010;2:86-92.

10. Pokharkar R.D., Funde P.E., Joshi S.S., Pingale S.S. Synthesis and characterization of fatty acid methyl ester by in-situ transesterification in Capparisdeciduas seed. Leonardo Electron. J. Pract. Technol. 2008;13:12-18.

11. Saxena V.K., Goutam A. Isolation and study of the flavone glycoside; luteolin-7-O- $\beta$-dglucopyranoside from the seeds of the Capparis decidua (Forsk.). Int. J. Chem. Sci. 2008;6:7-10.

12. Gupta J., Ali M. Oxygenated heterocyclic constituents from Capparis decidua root-barks. Indian J. Heterocycl. Chem. 1997;6:295-302.

13. Ahmad V.U., Arif S., Amber A.R., Usmanghani K., Miana C.A. A new spermidine alkaloid from Capparis decidua. Heterocycles. 1985; 23: 3015-3020.

21. Ahmad V.U. Further studies on the chemical constituents of Pakistani medicinal plants. Stud. Org. Chem. 1986;26:1-23.

23. Ahmad V.U., Arif S., Amber A.R., Nasir M.A., Ghani K.U. A new alkaloid from root bark of Capparis decidua. Z. Fuer Naturforschung Teil B. 1986;41b:1033-1035.

24. Ahmad V.U., Arif S., Amber A.R., Fizza K. Capparisinine, a new alkaloid from Capparis decidua. Liebigs Ann. Chem. 1987;2:161-162.

28. Chauhan E.M., Duhan A., Bhat C.M. Nutritional value of ker (Capparis decidua) fruit. J. Food Sci. Technol. 1986;23:106-108.

29. Dahot M.U. Chemical evaluation of the nutritive value of flowers and fruits of Capparis decidua. J. Chem. Soc. Pak. 1993;15:78-81.

30. Goyal M., Nagori B.P., Sasmal D. Sedative and anticonvulsant effects of an alcoholic extract of Capparis decidua. J. Nat. Med. 2009;63:375-379.

31. Upadhyay R.K., Ahmad S., Tripathi R., Rohtagi L., Jain S.C. Screening of antimicrobial potential of extracts and pure compounds isolated from Capparis decidua. J. Med. Plants Res. 2010;4:439-445.

35. Kala CP, Dhyani PP, Sajwan BS. Developing the medicinal plants sector in northern India: challenges and opportunities. Journal of Ethnobiology and Ethnomedicine. 2006; 2(1):32.

36. Modak M, Dixit P, Londhe J, Ghaskadbi S, Devasagayam TP. Recent Advances in Indian Herbal Drug Research. Journal of clinical biochemistry and nutrition. 2007; 40(3):163-73. 
37. Verma PD, Dangar RD, Shah KN, Gandhi DM, Suhagia BN. (2011). Pharmacognostical Potential of Capparis decidua Edgew. Journal of Applied Pharmaceutical Science 01(10):06-11.

38. Singh P, Mishra G, Srivastava S, Jha KK, Khosa RL. Traditional uses, phytochemistry and pharmacological properties of Capparis decidua: An overview. Der Pharmacia Lettre. 2011; 3(2):71-82.

39. Joseph B, Jini D. (2011)A medicinal potency of Capparis decidua-A harsh terrain plant. Res. J. Phytochem.5(1):1-3.

40. Nazar S, MuhammadA.Hussain MA, Tahir MN. (2020). Capparis decidua Edgew (Forssk.): A comprehensive review of its traditional uses, phytochemistry, pharmacology and nutrapharmaceutical potential. Arabian Journal of Che mistry. (13) 1: 1901 - 1916 . https://doi.org/10.1016/j.arabjc.2018.02.007

41. Abra HH and Ali M. (2011). Phytochemistry and bioactivities of a harsh Terrain plant: Capparis decidua (Forsk.) Edgew. Natural Products An Indian Journal. 7(4):222-229.

42. Rathee S., Mogla O.P., Rathee P., Rathee D. Quantification of $\beta$-sitosterol using HPTLC from Capparis decidua (Forsk.) Edgew. Pharma Chem. 2010;2:86-92.

43. Pokharkar R.D., Funde P.E., Joshi S.S., Pingale S.S. Synthesis and characterization of fatty acid methyl ester by in-situ transesterification in Capparis deciduas seed. Leonardo Electron. J. Pract. Technol. 2008;13:12-18.

44. Saxena V.K., Goutam A. Isolation and study of the flavone glycoside; luteolin-7-O- $\beta$-dglucopyranoside from the seeds of the Capparis decidua (Forsk.) . Int. J. Chem. Sci. 2008. 6:7-10.

45. Gupta J., Ali M. Oxygenated heterocyclic constituents from Capparis decidua root-barks. Indian J. Heterocycl. Chem. 1997; 6:295-302.

46. Ahmad V.U., Arif S., Amber A.R., Usmanghani K., Miana C.A. A new spermidine alkaloid from Capparis decidua. Heterocycles. 1985; 23: 3015-3020.

47. Ahmad V.U. Further studies on the chemical constituents of Pakistani medicinal plants. Stud. Org. Chem. 1986;26:1-23.
48. Ahmad V.U., Arif S., Amber A.R., Nasir M.A., Ghani K.U. A new alkaloid from root bark of Capparis decidua. Z. Fuer Naturforschung Teil B. 1986;41b:1033-1035.

49. Ahmad V.U., Arif S., Amber A.R., Fizza K. Capparisinine, a new alkaloid from Capparis decidua. Liebigs Ann. Chem. 1987;2:161-162.

50. Ahmad V.U., Ismail N., Amber A.R. Isocodonocarpine from Capparis decidua. Phytochemistry. 1989; 28:2493-2495.

51. Ahmad V.U., Ismail N., Arif S., Amber A.R. Two new $\mathrm{N}$-acetylated spermidine alkaloids from Capparis decidua. J. Nat. Prod. 1992; 55: 1509-1512.

52. Juneja T.R., Gaind K.N., Panesar A.S. Capparis decidua. Study of isothiocyanate glucoside. Res. Bull. Panjab Univ. Sci. 1970;21:519-521.

53. Chauhan E.M., Duhan A., Bhat C.M. Nutritional value of ker (Capparis decidua) fruit. J. Food Sci. Technol. 1986;23:106-108.

54. Dahot M.U. Chemical evaluation of the nutritive value of flowers and fruits of Capparis decidua. J. Chem. Soc. Pak. 1993;15:78-81.

55. Goyal M., Nagori B.P., Sasmal D. Sedative and anticonvulsant effects of an alcoholic extract of Capparis decidua. J. Nat. Med. 2009;63:375-379.

56. Garg P., Sachdeva K., Bhandari I. Phytochemical and pharmacological evaluation of Capparis decidua (Forsk.) Edgew stem for central nervous system depressant activity. Pharmacologyonline. 2011;2:146-155.

57. Gaind K.N., Juneja T.R., Bhandarkar P.N. Volatile principle from seeds of Capparis decidua. Kinetics of in vitro antibacterial activity against Vibrio cholerae ogava, inaba, and eltor. Indian J. Pharm. 1972;34:86-88.

58. Upadhyay R.K., Ahmad S., Tripathi R., Rohtagi L., Jain S.C. Screening of antimicrobial potential of extracts and pure compounds isolated from Capparis decidua. J. Med. Plants Res. 2010;4:439-445.

59. Ali S.A., Al-Amin T.H., Mohamed A.H., Gameel A.A. Hepatoprotective activity of aqueous and methanolic extracts of Capparis decidua stems against carbon tetrachloride induced liver damage in rats. J. Pharmacol. Toxicol. 2009;4:167-172. 
59. Goyal R., Grewal R.B. The influence of teent (Capparis decidua) on human plasma triglycerides, total lipids and phospholipids. Nutr. Health. 2003;17:71-76.

60. Purohit A., Vyas K.B. Hypolipidaemic efficacy of Capparis decidua fruit and shoot extracts in cholesterol fed rabbits. Indian J. Exp. Biol. 2005;43:863-866.

61. Yadav P., Sarkar S., Bhatnagar D. Action of Capparis decidua against alloxan-induced oxidative stress and diabetes in rat tissues. Pharmacol. Res. 1997;36:221-228.

62. Rathee S., Mogla O.P., Sardana S., Vats M., Rathee P. Antidiabetic activity of Capparis decidua Forsk Edgew. J. Pharm. Res. 2010;3:231-234.

63. Ghulam S. Ph.D Dissertation. University of Karachi; 2002. [accessed on November 15, 2011]. The Phytochemical and Phytopharmacological Studies on Saraca indica, Capparis decidua and Lotus gracinii. Available online: http://eprints.hec.gov.pk/1131/1/853.html.htm.

64. Kirtikar K., Basu B.D. Indian Medicinal Plants. 2nd ed. International Book Distributors; Rajpur Road, Dehradun, India: 1987.
65. Chahlia N. 2009 Preliminary studies into the hypolipidemic activity of various parts of Capparis decidua. Ethnobot. Leafl. 2009;13:332-337.

66. Rashid S., Lodhi F., Ahmad M., Usmanghani K. Preliminary cardiovascular activity evaluation of capparidisine, a spermidine alkaloid from Capparis decidua. Pak. J. Pharm. 1989;6:61-66.

67. Eliman M.E., Awad T.M. A note on the proximate analysis of different parts of Acacia tortilis, A.nilotica and Capparis decidua in the Gezira (Sudan) J. Agric. Sci. 2002;10:338-342.

68. Özcan M., Haciseferođullar H., Demi F. Some physico-mechanic and chemical properties of capers (Capparis ovata Desf. var. canescens (Coss.) Heywood) flower buds. J. Food Eng. 2004;65:151-155.

69. Rajesh P., Latha S., Selvamani P., Kanna V.R. Phytochemical Screening and Toxicity Studies on the Leaves of Capparis sepiaria Linn. (Capparidaceae) J. Basic Clin. Pharm. 1989;1:41-46.

70. Gupta A.S., Chakrabarty M.M. Composition of the seed fats of the Capparidaceae family. J. Sci. Food Agric. 1964;15:69-73. 